\title{
The Economic Heritage of an Iowa County
}

\section{Lee Soltow}

WHEN I WAS A BOY in Sac City, Iowa, my father many times characterized for me what he believed was the only motive of all Iowans. He thought it was solely to accumulate wealth. Every father who inherits one farm must pass two on to his son if he is serving a worthwhile purpose in life. This son, in turn, must leave a larger amount for the grandson. My father never went into the particulars of whether this was an arithmetic or geometric process of economic growth, but the ideas of the accusation are intriguing. 1) Each individual accumulates throughout his lifetime. 2) Some families have been in the area longer than others; they have been accumulating for longer periods than others so that there may be a large concentration of wealth. 3) Economic growth would have to take place if every family achieved this goal, unless outsiders or immigrants came in to produce a countervailing effect. 4) Society is so preoccupied with economic accumulation that it never does anything else. It is, in short, a culturally deprived society.

I would like to explore some of these ideas in depth. The economic aspects are subject to empirical testing, and use will be made of statistical material, particularly at the time of the formation of Sac County. The data show the very pervasive influence of the economic process of the society. The views concerning the cultural milieu associated with this growth process are only vaguely quantifiable. They are nevertheless of utmost importance and must be discussed. We shall consider the lives and writings of Iowa's intellectual elite in dealing with this problem.

\section{Economic Homogeneity}

The scattered figures that are available indicate that Sac 
County has always had remarkably little wealth inequality and might come as close to being a classless society as any in the country, considering its size. The first settler appeared in 1853 , leaving two years later because "folks is gettin' too thick." By 1860 , there were 64 males 20 years old and over; this number increased fivefold to 397 by 1870 . The 1870 population passed the level of 2 persons per square mile, a figure suggested to be typical of a frontier county by Frederick Jackson Turner.

We are fortunate to have the census wealth declarations of each individual in 1860 and 1870 , where wealth was defined as real estate and personal estate. These data are of fundamental importance in understanding the economic concepts of economic growth of class or classless society and individual wealth accumulation which were established in this very formative and sensitive period of Sac County's growth. ' Frequency distributions for the county and for the state are presented in Table 1 . It is really rather remarkable that only seven years after the claims were made, arithmetic mean wealth of these pioneers was $\bar{X}=$ $\$ 1,105$. The 1870 average of $\$ 1,995$ was $\$ 1,414$ when adjusted to 1860 prices. This yields an average annual rate of change of 2.6 per cent during the decade. These pioneers must have sensed, aside from their own individual betterment, that society as a whole had strong economic growth. Perhaps the reader finds the statement self-evident. One must remember that the influx of individuals was largely one of younger, less-affluent elements and that an average for individuals might decrease, while each older member experiences his own individual economic growth.

The question of economic class is confronted by exploring the difference in wealth between two individuals in some average sense. If one were to average all the possible paired differences in wealth of the 64 men in Sac County in 1860, he would find that it was $\Delta_{1860}=\$ 1,360$. Two individuals in the county, meeting by

'Suppose two men have wealth values of \$1 and \$5. Their mean, with its symbol of $\bar{X}$, is the aggregate divided by the number of men or $\$ 3$. The mean difference, with its symbol of $\Delta$, considers the average of all the possible paired differences in wealth of each individual from every other individual including himself. In this case we average the four absolute differences 5-1, 5-5, 1-5, and $1-1$ in obtaining a mean difference of $\$ 2$. The Gini coefficient, with its symbol of $R$, is the ratio of the mean difference divided by two times the mean; its value for our two men is $\$ 2 /(2 \times \$ 3)$ or .33. Further interpretations are given in the text. The symbol with a subscript 1860 signifies we are working with data for 1860 . 
Table 1

The Distribution of Wealth Among Males 20 Years Old and Over in Sac County in 1860 and 1870 and Iowa in 1860

\begin{tabular}{|c|c|c|c|c|c|c|}
\hline \multirow{3}{*}{$\begin{array}{l}\text { Lower limit } \\
\text { of wealth } \\
\text { class in } \\
\text { dollars }\end{array}$} & \multicolumn{4}{|c|}{ Sac County } & \multirow{2}{*}{\multicolumn{2}{|c|}{$\begin{array}{l}\text { Iowa } \\
1860 \\
\end{array}$}} \\
\hline & \multicolumn{2}{|c|}{1860} & \multicolumn{2}{|c|}{1870} & & \\
\hline & $\begin{array}{c}\text { Number } \\
\text { of males } \\
\text { in the } \\
\text { wealth } \\
\text { class }\end{array}$ & $\begin{array}{l}\text { Per Cent } \\
\text { of males } \\
\text { above X }\end{array}$ & $\begin{array}{l}\text { Number } \\
\text { of males } \\
\text { in the } \\
\text { wealth } \\
\text { class }\end{array}$ & $\begin{array}{l}\text { Per Cent } \\
\text { of males } \\
\text { above X }\end{array}$ & $\begin{array}{l}\text { Number } \\
\text { of males } \\
\text { in the } \\
\text { wealth } \\
\text { class }\end{array}$ & $\begin{array}{l}\text { Per Cent } \\
\text { of males } \\
\text { above X }\end{array}$ \\
\hline 0 - & 10 & 100 & 70 & 100 & 42,720 & 100 \\
\hline $10-$ & 3 & 84 & $\{13$ & 82 & 9.040 & 74 \\
\hline $100-$ & 5 & 80 & & 02 & 9,360 & 69 \\
\hline $200-$ & 9 & 72 & 24 & 79 & 14.560 & 64 \\
\hline $400-$ & 14 & 58 & 83 & 73 & 27,440 & 54 \\
\hline 1.000 & 10 & 36 & 86 & 52 & 28,480 & 38 \\
\hline $2,000-$ & 9 & 20 & 74 & 30 & 21,280 & 21 \\
\hline 4.000 & 4 & 6 & 38 & 12 & 9,680 & 8 \\
\hline 10,000 & - & & 6 & 2.3 & 2,480 & 2.0 \\
\hline 20.000 & - & & 2 & .8 & 598 & .5 \\
\hline 40,000 & - & & 1 & .3 & 222 & .2 \\
\hline \multirow[t]{2}{*}{100.000} & $=$ & & - & & 54 & \\
\hline & $\overline{64}$ & & 397 & & 165.914 & \\
\hline $\begin{array}{l}\text { Arithmetic } \\
\text { mean }\end{array}$ & \multicolumn{2}{|c|}{$\$ 1.105$} & \multicolumn{2}{|c|}{$\$ 1.995$} & \multicolumn{2}{|c|}{$\$ 1.517$} \\
\hline Median & \multicolumn{2}{|c|}{$\$ 685$} & \multicolumn{2}{|c|}{$\$ 1.055$} & \multicolumn{2}{|c|}{$\$ 500$} \\
\hline $\begin{array}{l}\text { Ginior } \\
\text { concentration } \\
\text { coefficient }\end{array}$ & \multicolumn{2}{|c|}{.62} & \multicolumn{2}{|c|}{.64} & & .73 \\
\hline
\end{tabular}

Source: Schedule 1 of the 1860-70 Census manuscripts. The Sac County distributions are complete enumerations. The Iowa distribution was obtained by taking a complete enumeration of all wealth values above $\$ 20,000$. A random sample below this level was drawn by taking approximately 1 of each 80 males.

chance, would have an expected difference in wealth of $\$ 1,360$. This mean difference, expressed as a per cent of the mean, is $\Delta_{1860} / \bar{X}=\$ 1,360 / \$ 1,105$. The procedure gives us a relative measure at a point in time and place which may be compared readily to that in some other time and place. One further refinement gives a well-known measure of inequality, the Gini coefficient, $R=\Delta / 2 \bar{X}=\$ 1,360 / 2(\$ 1,105)=.62$. The factor of 2 is a mathematical nicety which conveniently gives a value of $R=0.0$ if there is no inequality and $R=1.0$ if one person had all wealth. 
Sac County's inequality level may be compared to that in other areas.

$$
\begin{aligned}
& R_{1800, \text { Sac }}=.62 \\
& R_{1800, \text { Iowa }}=.73 \\
& R_{1800, \text { United States }}=.84 \\
& R_{1875, \text { Great Britian, acreage only }}=.86
\end{aligned}
$$

It is seen that the expected relative wealth difference between two individuals within the county was substantially less than that arising from two individuals meeting from within larger areas. The Gini coefficient is not known for very many of the 2,105 counties in the United States in 1860. The 10 most-heavily-populated counties had coefficients which averaged .90. In Wisconsin, the 56 effective counties had coefficients averaging . 71 , while the coefficient for the state was .75. Very few of Wisconsin's frontier counties in 1860 and 1870 had coefficients as low as those in Sac County. ${ }^{2}$

In speaking of Sac County, we are dealing with a relatively homogeneous group. This does not mean that an individual in the county had wealth which was atypical for the state. Average wealth per adult was between $\$ 281$ and $\$ 999$ for 10 counties, $\$ 1,000$ and $\$ 1,999$ for 78 counties, and $\$ 2,000$ and $\$ 2,645$ for 9 of the state's 97 counties reporting adult males. ${ }^{3}$ Assuming each individual in the county had a wealth value equivalent to the aver-

${ }^{2}$ The sampling size for a county may have to be almost as large as that for a state, thus necessitating a formidable amount of work. The values given here are essentially unpublished results in the case of Sac County and Iowa. Wisconsin data are from Lee Soltow, Patterns of Wealthholding in Wisconsin Since 1850 (Madison: University of Wisconsin Press, 1971) 63. Large-county figures are from Soltow, "The Wealth, Income, and Social Class of Men in Large Northern Cities of the United States in 1860," Personal Distributions of Income and Wealth. James D. Smith, Editor, 39, Series in Income and Wealth, National Bureau of Economic Research (New York, 1974). Further information is contained in Soltow, Men and Wealth in the United States: 1850-1870. (Yale University Press). The value for Great Britain is given in Soltow, "Long-Run Changes in British Income Inequality," Wealth, Income, and Inequality, A. B. Atkinson, Editor, (Penguin Education, London 1973), 95-96 or in Essays in Quantitative Economic History, Roderick Floud, Editor, (London: Oxford University Press, 1974), 163.

${ }^{3}$ This average was obtained using the published aggregate of wealth for the county for all men, women, and children. This aggregate was divided by the number of males 20 and older in each county in order to obtain the 97 values listed. 
age wealth in the county leads to an $R$ of only .11 for Iowa in 1860. Area (county) differences thus were not important.

Rural and urban differences within areas were much more important. If we use the dichotomy, farmer-nonfarmer as an approximation, we have

\begin{tabular}{|c|c|c|c|}
\hline & farmer & nonfarmer & all \\
\hline$R_{1 \times 6}$ & .59 & .66 & .62 \\
\hline$R_{1 \text { sา }}, \mathrm{Sac}$ & .59 & .78 & .64 \\
\hline$R_{\text {1soo, Iowa }}$ & .66 & .83 & .73 \\
\hline
\end{tabular}

Perhaps this aspect is the quanitification of the obvious. There was greater economic heterogeneity in the nonfarm sector. If heterogeneity serves as a goad to cultural activitiy, it would be more prevalent in the urban than in the rural sector. Even inequality in the rural sector of all the nonslave states and territories in 1860 was less than that among nonfarmers in Sac County, Iowa. An alternative is to emphasize that nonfarmers in Sac City had little more inequality than farmers in large areas. ${ }^{4}$

We have discussed general economic growth and inequality. The third and most important aspect of the economic spirit of the time was individual wealth accumulation. One can delve more

${ }^{4}$ George F. Parker ( -1928) wrote in Iowa-Pioneer Foundation (two volumes, lowa City: 1940), impressions of pioneers in the period from 1830 to 1870 garnered in part from personal knowledge of these individuals. He disbelieved (Vol. II, pp. 305-325) that there was equality and classlessness among the pioneers because of differences of abilities and conditions.

Parker constructed a scheme of four socio-economic classes of men. 1. The good, constituting 8 to 10 per cent of the population. These men picked out the best land early in the settlement period. They were active, intelligent, educated, often unconscious leaders of civil administration. They were prominent in such fields as collecting taxes, supervising road and bridge construction, and supporting religious and educational institutions. 2 . The oftentimes respectable and sturdy, constituted 75 per cent of the population. These people did not know how to select the best land; they were more likely to be "litigious or quarrelsome." There was a pattern of letting livestock feed on neighbors' land, permitting houses, barns, and fences to dilapidate, hiding crooked sticks in the middle of a load, and selecting the best potatoes or ears for the top of a load. 3 . The low-type people, constituting 7 to 10 per cent of the population. These were idlers and parasites who would not work. 4. The foreign-language element. This group was honorable and industrious, but did not fit into the main stream of affairs.

It is noteworthy that Parker found the lazy to be such a small group. The fact that the good arrived first and were cognizant of the need for improvements is, at least in part, a recognition of age and higher wealth. Didn't those with more wealth have more products for market and higher consumption standards? 
thoroughly into individual changes by using age as a proxy for time. Its results are fascinating because the mechanism explains, more than with any method at our disposal, the principles of self-reliance in individual betterment. The data of betterment are given in Table 2. It is noted that Sac County age distributions are similar to that for the state. The median age is only 32 or 33 since there are so many in the age class from 20 to 29 .

Table 2

The Number and Average Wealth in Sac County in 1860 and 1870 and in Iowa in 1860 of Males 20 Years Old and Over, Classified by Age Class

\begin{tabular}{|c|c|c|c|}
\hline \multirow{3}{*}{$\begin{array}{l}\text { Class limits } \\
\text { of age class }\end{array}$} & \multicolumn{3}{|c|}{ Number of adult males } \\
\hline & \multicolumn{2}{|c|}{ Sac County } & Iowa \\
\hline & 1860 & 1870 & 1860 \\
\hline $20-29$ & 21 & 169 & 59.475 \\
\hline $30-39$ & 20 & 103 & 51.084 \\
\hline $40-49$ & 12 & 63 & 29.694 \\
\hline $50-59$ & 8 & 39 & 17,286 \\
\hline $60-69$ & 1 & 20 & 5,884 \\
\hline \multirow[t]{3}{*}{$70 \& u p$} & 2 & 3 & 2.491 \\
\hline & $\overline{64}$ & $\overline{397}$ & 165.914 \\
\hline & \multicolumn{3}{|c|}{ Average wealth, adjusted to 1860 prices } \\
\hline \multirow{2}{*}{$\begin{array}{l}\text { Class limits } \\
\text { of age class }\end{array}$} & \multicolumn{2}{|c|}{ Sac County } & Iowa \\
\hline & 1860 & 1870 & 1860 \\
\hline $20-29$ & $\$ 565$ & $\$ 638$ & $\$ 577$ \\
\hline $30-39$ & 1.457 & 1.726 & 1.477 \\
\hline $40-49$ & 1,192 & 2.831 & 2,696 \\
\hline $50-59$ & 1.552 & 1,800 & 2.766 \\
\hline $60-69$ & 1,250 & 1.236 & 1.830 \\
\hline $70 \& u p$ & 750 & 335 & 1.320 \\
\hline
\end{tabular}

Source: Schedule 1 of the 1860-70 Census manuscripts. The price deflator of 1870 was $141(100=1860)$ as taken from Trends in the American Economy in the Nineteenth Century, Studies in Income and Wealth, Vol. 24, pp. 142. 143. 
Let us focus our attention on the wealth averages in the lower portion of Table 2. The Sac County averages in 1860 indicate that those of age 30-39 have sizeable wealth as compared to those 10 years younger. $\left(\bar{X}_{30-39} / \bar{X}_{20-29}\right.$ for Sac in 1860 , Sac in 1870 , and Iowa in 1860$)=(2.56,2.66,2.56)$. It is as though those who had been in the county or state 10 years longer as adults, had experienced rapid economic growth.

We next note that the average for those $40-49$ or 40 and older in Sac in 1860 is no larger than the average of those $30-39 .\left(\bar{X}_{40-49}\right.$ $/ \bar{X}_{30-39}$ for Sac 1860 , Sac 1870 , Iowa 1860$)=(.82,1.64,1.83)$. The results for 1860 and 1870 are contradictory for Sac County. The 1860 figures give no implication of growth but the 1870 figures do. Aren't we led almost automatically to the fact that the county was 7 years old in 1860 and 17 years old in 1870 ? Aren't we witnessing, for broad aggregate groups, those who have been exposed to accumulation for 20 years instead of 10 years?

Let us carry the procedure one more decade or, at least, one more age interval by noting that $\bar{X}_{50-59} / \bar{X}_{40-49}$ is a ratio less than one in Sac County in 1870, but greater than one in Iowa for 1860. This is at least somewhat tenuous evidence that individuals in the more densely populated areas of the state experienced accumulation for 30 years. We are unable to effectively trace given individuals over long periods of time. We must limit ourselves to the remarkable censuses of 1850,1860 , and 1870 . Even here it is most discouraging to try to trace one individual from one census to the next. We confine ourselves to age cohorts in 1860 and 1870 in making some growth inferences. Essentially one looks at the Iowa distribution in 1860 (or 1870) in making age-specific comparisons. It is argued that age is a proxy for time and that one can, in effect, measure trend from the age-specific values.

Fiting a linear exponential trend to the values for Iowa gives:

Age $\quad$ of points $\quad \begin{gathered}\text { Number } \\ \text { Implicit average annual } \\ \text { rate of growth }\end{gathered}$

$\begin{array}{lll}20-29 \text { to } 50-59 & 4 & 5.5 \text { per cent } \\ 20-29 \text { to } 60-69 & 5 & 3.0 \text { per cent } \\ 20-29 \text { to } 70-79 & 6 & 1.4 \text { per cent }\end{array}$

Similar rates are found when the classification is limited to native- 
born males. It would seem that a working life span might be from age 20 to 59 and that a 5.5 per cent annual accumulation rate is appropriate. It is a handsome rate indeed and must have pervaded the thoughts and actions of people. More elaborate statistical techniques may be applied to the population and wealth figures. These yield implications of economic growth per capita. The effect of the large influx of young at the lower rung of the wealth ladder severely lessens per capita growth, but not to the point of making it negative.

It will be maintained later on in this essay that the experience of a boy in this economic environment affects his later activities and outlook. It may seem that figures for 1860 and 1870 have little bearing on the present or immediate past. Consider, however, that 1860 and 1870 are not far removed for the birth dates of, among Iowans: Hamlin Garland in 1860, Herbert Quick in 1861, John L. Lewis in 1880, James Norman Hall in 1887, Henry A. Wallace in 1888, Harry Hopkins in 1890 , Grant Wood in 1892 , Meredith Willson in 1902, MacKinlay Kantor in 1904, and Paul Engle in 1908.

We do not know with certainty if accumulation rates continued at their 1860-1870 pace. Certain data on the value of farms and homes of individuals, classified by age, were gathered in the 1890 census. Midwest tables for the year reflect age group differentials similar to those discussed above for Iowa in 1860. Certain national data for estates have similar ramifications for the year 1922. One does not have actual information for individuals for Sac County after 1870 . I merely will assert that these beginning influences continued to pervade the philosophy of men. ${ }^{5}$

It is possible to say more about inequality in Sac County after 1870 after examining the distribution of farm acreage among farmers. The distributions for three years over the century are given in Table 3 for the county and for the state. The land inequality remained relatively constant as shown by the values of the Gini Coefficient in 1860, 1910, and 1959 of .24, .33, and .33 for Sac County and $.38, .37$, and .34 for Iowa. The low coefficient

'I made an abortive attempt to examine estates in the Sac County Court House. The 1890 data are in United States Census, 1890, Farms and Homes: Proprietorship and Indebtedness, Tables 81, 158, and 161 . The 1922 data are in Robert Lampman, The Share of Top Wealth-Holders in National Wealth. National Bureau of Economic Research (New York: 1962), 250, 257. 
Table 3

Distribution of Land in Farms in Sac County and in Iowa for the Selected Years 1860, 1910 and 1959

Number of Sac farms

Number
of
acres
$0-$
$3-$
$10-$
$20-$
$50-$
$100-$
$500-$
$1.000-$

Arithmetic mean

\section{Gini}

coefficient

1860,
improved
land only

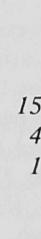

$\overline{20}$

45 acres

.24
1910, all farm land

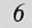

74

36

70

247

1,567

10

$\frac{4}{2.014}$

179 acres

205 acres

.33
1959, all

farm land

$\{63$

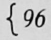

101

1.448

33

$\frac{5}{1.746}$

for the county in 1860 is a reflection of only 7 years of settlement. It is noted that each farm in Sac County in 1860 had at least 20 acres of improved land. Income (as distinguished from wealth) distributions are available for 1949 and 1959. The distributions in 1959 for all males with income curiously had the same Gini coefficients in Sac County and in the United States. ${ }^{\circ}$ Sociologists gener-

-The value of $R$ was .43. U.S. Bureau of the Census, U.S. Census of Population 1960. General Social and Economic Characteristics. U.S. Summary. Final Report PC(1)-1C (Washington: 1962), 287, 288, and Vol. 1, part 17, 276. The midvalue of the highest-income class above $\$ 10,000$ was assumed to be $\$ 16,700$. the value for Iowa obtained from U.S. Treasury Department, Statistics of Income Tax Returns. 1959. 77-85. Evidence from the income tax data of the period from 1863 to 1872 and from 1913 to date suggests that income inequality may have decreased substantially in urban areas while remaining fairly constant in rural areas. This is due, in part, to the fact that rural distributions are more directly related to wealth inequality in land. The land distributions given in Table 3 do not reflect multiple farm ownership, land-fertility differences, distance to markets, propertyless hired men, or city dwellers. 
Table 3, continued

Number of farms in Iowa

\begin{tabular}{|c|c|c|c|}
\hline $\begin{array}{l}\text { Number } \\
\text { of } \\
\text { acres }\end{array}$ & $\begin{array}{c}1860, \\
\text { improved } \\
\text { land only }\end{array}$ & $\begin{array}{l}1910, \text { all } \\
\text { farm land }\end{array}$ & $\begin{array}{l}\text { 1959, all } \\
\text { farm land }\end{array}$ \\
\hline $0-$ & & $\begin{array}{r}392 \\
7\end{array}$ & $\{5.457$ \\
\hline $\begin{array}{r}3- \\
10-\end{array}$ & $\begin{array}{r}951 \\
4.272\end{array}$ & $\begin{array}{l}7,295 \\
6.037\end{array}$ & \\
\hline 20 - & 24,139 & 15.678 & $\{13.727$ \\
\hline $50-$ & 19.670 & 38.712 & 18.559 \\
\hline $100-$ & 10.521 & 146.286 & 132.144 \\
\hline $500-$ & 66 & 2,430 & 4.475 \\
\hline \multirow[t]{2}{*}{1.000} & 10 & 214 & 345 \\
\hline & $\overline{59,629}$ & 217,044 & 174,707 \\
\hline $\begin{array}{c}\text { Arithmetic } \\
\text { mean }\end{array}$ & 63 acres & 156 acres & 194 acres \\
\hline $\begin{array}{l}\text { Gini } \\
\text { coetficient }\end{array}$ & .38 & .37 & .34 \\
\hline
\end{tabular}

Census of Agriculture 1860, pp. 46, 184, 199; Census of Agriculture, 1910 Iowa, pp. 520-528; Census of Agriculture 1959, Vol. 1. part 16, pp. 118-124.

ally have considered income less indicative than wealth as a measure of social class. This is because wealth is accumulated over a long period of time; in one sense it is the product of many years of income.

There is an element of inconsistency in our two findings, individual wealth accumulation and constant wealth inequality in Sac County and in Iowa. Shouldn't those families accumulating the longest length of time ultimately obtain a larger share of the total wealth as compared to those just moving into the community? Won't the rich get richer even though new poor can begin to accumulate? A tacit assumption is that the institution of inheritance leaves the estate intact. This could occur in a land without primogeniture if the rich intermarry by pairing up on the basis of an arrayed wealth list and if they do no more than reproduce 
themselves. But both of these rules are violated in an open and growing society. It is not uncommon that a man and wife have 3 children. The average inheritance of the progeny is less than that of the decedent. If two families, having estates of $\$ 10,000$ each and 3 children each, arrange intermarriage between their children, the average inheritance of the three pairs of children would be $\$ 6,667$. The largest ranch in Sac County at the turn of the century encompassed 12 sections. Its dissolution was apparently brought about because of many heirs.

\section{Cultural Heterogeneity}

It has been established that there was: 1) relatively little wealth inequality coupled with 2) strong individual accumulation throughout one's normal working years in Sac County. Let us over-generalize by saying it was and is a one-class society of economic determinism. The question to be discussed now is what effect this heritage, or state of affairs, has on the level of the arts and culture, or other flourishing endeavor outside the economic sphere.

Most writers seem to feel that both equality and growth militate against cultural development. Equality pacifies you while a larger GNP engine mesmerizes you, embracing you and your activities. Heterogeneity or inequality acts as a continual goad to reexamine the social and cultural system, one's objectives in life, one's activities. W. J. Cash in The Mind of the South attempts to formulate reasons why the antebellum South was allegedly moribund from a cultural standpoint. He wrote that it was not a complex society. There was no social dissatisfaction. He maintained that one would not analyze society without this complexity. This argument seems to fit Sac County since such a large number were farmers. In the earliest period in Sac County in 1860 and 1870 and Iowa in 1860 , the per cent of adult males reporting specifically that they were farmers or farm laborers was respectively 61 , 81 , and 61 . Even in 1960 , the per cent of the male labor force classified in farming was 48 in Sac County and 27 in Iowa. ' How could such a homogeneous occupational grouping hope to produce other than accumulations of wealth?

I shall turn the arguments around somewhat and entertain the

'U.S. Bureau of the Census, U.S. Census of Population, 1960, I, 18-181 and 17-260. 
thesis that this economic environment was not a deterrent but a stimulus to creative activity. It is admitted that this stimulus has come largely from men living in towns, but the town life was and is determined by the farm sector. The points to be considered are very much in the realm of speculation.

\section{Classlessness}

It is probable that the relative classlessness made and makes it possible for one to know many individuals in the town, to be acquainted on more than a casual basis with people from varied backgrounds. This is more than a question of the size of the community. One knows individuals from a wide variety of different percentile ranges of the wealth distribution. This is due to the small differences in wealth values between these percentile groups. But it can mean more. If the median person knows individuals 30 percentile ranges from himself, why not know individuals from 50 percentile ranges away? The horizon once broadened is broadened further.

This makes one more cognizant, more openly aware, of all individuals in the communities, their strengths and weaknesses. One might very well be more interested in wider economic groups than in other societies. Specifically, the Gini coefficient of wealth of the total set known could be greater than the Gini coefficient of the smaller relative subset known to individuals in other regions, particularly in the South, Northeast, or in the cities of the country.

I remember clearly a conversation I had with the nation's leading sociological statistician, Samuel Stouffer. A few years ago in Cambridge, I specifically asked him what his feelings were about having grown up in Sac City. I expected him to reply in a negative fashion, perhaps citing such aspects as poor schools. I was mistaken. He stated that he had been very fortunate to live in Sac City (a town, as contrasted to a large city) as a boy and young man because it made him much more aware of individuals as human beings, as persons with different strengths, weaknesses, and problems.

The thesis is that if one knows a relatively diverse group, he craves knowledge of even more diverse groups. This curiosity may apply only to some few with perspicacious minds. It may stem from the absence of initial negative feelings toward an individual 
or group. One can't get too disturbed if one individual with large wealth holds it in the form of land. The rich man is not really an immediate employer who must be contained by using a strike. There is a common story of a farm hand who terminated his employment with Sac County's largest land holder during the Depression. He related that he gave the rather standard retort, "The only difference between me and you, Mr. Adams, is that you're working on your second million and I'm working on my first."

\section{Productive Childhood and Avoidance of Adult Wealth Accumulation}

Iowa has produced a remarkable array of productive scholars and leaders, considering the size of its population. These include Hamlin Garland, Herbert Quick, Norman Hall, MacKinlay Kantor, Paul Engle, Grant Wood, Karl King, Meredith Willson, Buffalo Bill Cody, Charles Ringling, Billy Sunday, John L. Lewis, Herbert Hoover, Harry Hopkins, and Henry Wallace. I can do no more than to suggest a pattern that might be applicable to a few individuals growing up in towns the size of Sac City or larger. This pattern might make the probability a little higher than average that an individual might excel in creativity. It is based on the premise that a boy in a pre-Sputnik small town can have an exceedingly rich childhood within a somewhat narrow world. This experience makes it possible for him to rebel against or, at least, obviate the adult narrow world of wealth accumulation described earlier.

There can be great heterogeneity or variability of noneconomic variables. Extreme changes in weather can occur within a season or between seasons. Terrain may differ in elevation. A river or lake adds variety. Different land uses are determined by different crops. There are idle woodlands, a few store buildings, a railroad track, expansive house lots. There are many varieties of animals and birds. Here it is admitted that the small size of a town makes it possible for one to observe people, weather, and nature while taking short walks. It may take only 10 minutes to walk from the center of town to one of several points on the winding river, 20 to be at the scout cabin, 5 minutes to be in a position to walk along the railroad tracks, 12 minutes to be at the golf course, 5 minutes from swimming at the sand pit, 5 minutes from 
one park with a tennis court and 5 minutes from another with a ski hill, 5 minutes to another with the bandstand, 5 minutes to school, 3 minutes to the city library, or 10 minutes to anyone's house in town from the zero to one hundredth percentile in wealth.

How could any boy with spare time avoid this heterogeneity, this "inequality" of nature and man? Activities came and left with the seasons. These included marbles, mumbly-peg, kite-flying, skating down the river, going with a trapper on his rounds, gravel football, sitting in a tree house dreaming. Only the playing in the bandstand would not be classified within what Harold Taylor has called "Huck Finnism."

It would seem that a disproportionate few are well prepared to go into the world with a fresh approach. It would also seem that they must leave Sac City as adults, going at least to Des Moines, Ames, or Iowa City. They may not stop until they reach New York, Boston, Washington, or Pitcairn Island.

Some of the suggestions in the last few paragraphs perhaps could not be substantiated if one were to look at Iowa's creative people. Are Sioux City and Cedar Rapids small towns? Yes. It was not uncommon in Grant Wood's time to have a cow in outlying Cedar Rapids. ${ }^{8}$ Were creative persons interested in individuals? Consider that Iowa's three earliest writers were all sensitive to the plight of the individual. Hamlin Garland belonged to an antipoverty league in Boston. Herbert Quick was a "single taxer" and editor of La Follette's Weekly. James Norman Hall was engaged in social work in Boston. One surely would not assert that Herbert Hoover, John L. Lewis, Henry A. Wallace, and Harry Hopkins were indifferent to people.

It is Hamlin Garland (1860-1940) in his autobiographical novel, Son of the Middle Border, who is most revealing in his reaction to an agricultural economy. It is revealing even though some of his sentiments about farm life may be anathema to those who extol Iowa's life of the past. In considering his town life in Osage in 1875, he speaks of the "delicious sense of leisure," a community where one could "step across the way to watch a ball game." "We were in the center of the world." This center could

${ }^{8}$ Darrell Garwood, Artist in Iowa (New York: 1944), 26. 
have "frequent days off for fishing, swimming, berrying, and we were entirely content with life." He "attended every moment" when the circus came to town. Having tasted town life, he wrote of the "care-free companionable existence led by my friends in the village." At age 27 he returned from Boston to Osage, to observe the land, "musing upon its distinctive qualities, and while I acknowledged the natural beauty of it, I revolted from the gracelessness of human habitations." He gave no answers to his thoughtful question, "Why has this land no storytellers like those who have made Massachusetts and New Hampshire illustrious?"

Garland rebelled against hardships and inequities as an adult. He spoke out against inequality and millionaires. Even though he acknowledged economic growth in Osage and the accumulation of his father of much land in Dakota, he felt it was a futile life for people. It would have been so for him. But even he was happy in the thought that in later life he brought his parents back to La Crosse County, Wisconsin near the Iowa border while he went back to Chicago. What Garland perhaps failed to realize was that his father had participated in the attractive game of wealth accumulation. The father had one thousand acres of wheat when he left South Dakota. A creative man might find such a feat of wealth accumulation a narrow activity. It could be just that for one who can see further than the economic world. But it was this middle western economic world that made it possible for him to go beyond its economic homogeneity. 
Copyright of Annals of Iowa is the property of State of Iowa, by \& through the State Historical Society of Iowa and its content may not be copied or emailed to multiple sites or posted to a listserv without the copyright holder's express written permission. However, users may print, download, or email articles for individual use. 